\title{
South Africa: Integrated approach improves quality of post-rape
} care

Population Council

Follow this and additional works at: https://knowledgecommons.popcouncil.org/departments_sbsr-rh

Part of the Demography, Population, and Ecology Commons, Domestic and Intimate Partner Violence Commons, Family, Life Course, and Society Commons, Gender and Sexuality Commons, International Public Health Commons, Medicine and Health Commons, and the Women's Health Commons How does access to this work benefit you? Let us know!

\section{Recommended Citation}

"South Africa: Integrated approach improves quality of post-rape care," FRONTIERS OR Summary. Washington, DC: Population Council, 2008. 
South Africa
Integration

OR Summary 69

\section{Integrated Approach Improves Quality of Post-rape Care}

An integrated model for post-rape care by nurses in a rural district hospital, which included a designated room for medical management and guidelines for providing reproductive health and HIV services, improved the quality of care provided. However, nurses remained reluctant to collect forensic evidence that could be used for prosecuting perpetrators.

\section{Background}

South Africa has developed a strong policy framework outlining medical management of rape survivors, which includes provision of HIV testing and post-exposure prophylaxis (PEP) and emergency contraception, ideally within 72 hours. However, implementation has been hampered by numerous obstacles, both in health care infrastructure and policy, and in linkages between medical care and criminal justice services.

To address these issues, in 2004 FRONTIERS collaborated with the Rural AIDS and Development Action Research Programme (RADAR) of the University of Witwatersrand and the Tshwaranang Legal Advocacy Centre (TLAC) to develop and test a strengthened and integrated model for post-rape treatment. The study was implemented in a 450-bed district hospital serving a large rural population in Mpumalanga province. The intervention comprised five elements: (1) establishing a sexual violence advisory committee at the hospital; (2) instituting a hospital policy for rape management; (3) training clinicians, police, and social workers on post-rape care; (4) centralizing and coordinating post-rape care through a designated outpatient room; and (5) a community awareness campaign.

To assess the intervention's effectiveness, researchers conducted interviews with over 50 health care workers, pharmacists, police, and other service providers at the baseline and midway through the study. Quality of care was assessed through a review of 334 hospital charts and interviews with 109 rape survivors.

\section{Findings}

- Quality of care improved significantly after the model was implemented. Provision of VCT and PEP showed particular improvement, with over three times as many survivors receiving a full 28-day supply of PEP at the first visit (see Table). This was also reflected in a three-fold increase in patients reporting adherence to the full PEP regimen. Rape survivors had significantly more positive views of hospital services, staff attitudes, and counseling after the intervention.

- Consolidation of all rape-related treatments in one room led to increased service efficiency. The proportion of survivors who reported seeing six or more providers decreased from 86 to 54 percent.

- Nurses were able to provide high-quality medical management of post-rape cases, including documenting the rape history, providing and counseling on PEP and other medications, and making follow-up referrals. Many nurses were reluctant to learn and implement the forensic examination, citing a lack of clarity regarding their legal ability to testify in court if needed.

- The majority $(76 \%)$ of survivors reported to the police before coming to the hospital - both before and after the intervention - and most ( $80 \%$ ) presented to the hospital within 72 hours, and were thus eligible for medical treatment.

- One quarter of those presenting were children younger than age 14 and about one half were under age 18 . Several rape survivors were male. 


\begin{tabular}{|c|c|c|c|}
\hline \multicolumn{4}{|c|}{$\begin{array}{l}\text { Quality of care given to rape survivors, pre- and post- } \\
\text { intervention (Chart Review) }\end{array}$} \\
\hline \multicolumn{2}{|c|}{ Quality of care indicators } & $\begin{array}{c}\text { Pre-interven- } \\
\text { tion } \\
(n=161)\end{array}$ & $\begin{array}{l}\text { Post-inter- } \\
\text { vention } \\
(n=173)\end{array}$ \\
\hline \multirow{2}{*}{$\begin{array}{l}\text { Pregnancy } \\
\text { prevention }\end{array}$} & $\begin{array}{l}\text { Preg test } \\
\text { given }\end{array}$ & $68 \%$ & $86 \%$ \\
\hline & EC given & $65 \%$ & $73 \%$ \\
\hline STI & $\begin{array}{l}\text { STI meds } \\
\text { given }\end{array}$ & $88 \%$ & $92 \%$ \\
\hline \multirow{5}{*}{$\begin{array}{c}\text { VCT and } \\
\text { PEP }\end{array}$} & $\begin{array}{l}\text { Any VCT } \\
\text { done }\end{array}$ & $60 \%$ & $87 \%$ \\
\hline & $\begin{array}{l}\text { VCT on } \\
\text { first visit }\end{array}$ & $41 \%$ & $61 \%$ \\
\hline & $\begin{array}{l}\text { Any PEP } \\
\text { given }\end{array}$ & $48 \%$ & $72 \%$ \\
\hline & $\begin{array}{l}28 \text { days } \\
\text { given on } \\
1^{\text {st }} \text { visit }\end{array}$ & $15 \%$ & $55 \%$ \\
\hline & $\begin{array}{l}\text { Anti-emet- } \\
\text { ics given }\end{array}$ & $30 \%$ & $45 \%$ \\
\hline Referrals & $\begin{array}{c}\text { Other } \\
\text { providers }\end{array}$ & $19 \%$ & $46 \%$ \\
\hline
\end{tabular}

\section{Utilization}

- RADAR has provided technical assistance to train 650 health managers and health care workers in implementing the National Guidelines for Management of Sexual Assault, as well as the relevant hospital policies, management and provider tools, treatment algorithms, and approaches to monitoring and evaluation.

- Survivors' confidence in the judicial system remains low. TLAC has initiated provision of direct legal services to rape survivors and will extend the service to address the needs of women experiencing domestic violence.

\section{Policy Implications}

- Post-rape care can be effectively integrated into existing RH/HIV services at the district hospital level in South Africa. Introducing a hospital rape management policy may be important in establishing an institutional framework for coordinating care. Such a policy should lay out the responsibilities of a range of actors, beyond health care workers, to ensure quality care.

- Treatment protocols can systematize care and make it easier for providers to follow the National Management Guidelines. Such protocols are particularly important given the lack of training received by many healthcare workers.

- Because most survivors present to a hospital after-hours, all services, including VCT, should be made available 24 hours a day. Providing a stat dose of PEP can reduce the time to first dose. In resource-poor and/or rural areas where patients are unlikely to return to hospital, providing the full 28-day PEP regimen on first visit can improve treatment adherence

- The high proportion of post-rape clients that are adolescents and children indicates a need-both for police and health services - to develop policies to manage younger and male survivors, not only adult women.

- In the absence of comprehensive rape crisis centers, effective links must be established with police, legal and counseling services.

December 2007

Source: Kim, Julia et al. 2007. "Developing an integrated model for post-rape care and HIV post-exposure prophylaxis in rural South Africa," FRONTIERS Final Report. Washington, DC: Population Council. Available on our website at www.popcouncil.org/frontiers/frontiersfinalrpts.html or by e-mail: frontiers@popcouncil.org

This publication is made possible by the generous support of the American people through the United States Agency for International Development (USAID) under the terms of Cooperative Agreement No. HRN-A-00-98-00012-00. The contents are the responsibility of the FRONTIERS Program and do not necessarily reflect the views of USAID or the United States Government. 